\title{
MORPHOLOGICAL ABNORMALITIES IN THE CLADOCERAN Ilyocryptus spinifer (APIPUCOS RESERVOIR, PERNAMBUCO STATE, BRAZIL)
}

\author{
ELMOOR-LOUREIRO, L. M. A. \\ Laboratório de Zoologia, Universidade Católica de Brasília, QS 7, \\ Lote 1, Bloco M, Sala 331, CEP 72030-170, Taguatinga, DF, Brazil \\ Correspondence to: Lourdes M. A. Elmoor-Loureiro, Laboratório de Zoologia, Universidade Católica de Brasília, \\ QS 7, Lote 1, Bloco M, Sala 331, CEP 72030-170, Taguatinga, DF, Brazil, e-mail: lourdes@ucb.br \\ Received July 11, 2002 - Accepted June 6, 2003 - Distributed February 29, 2004
}

(With 11 figures)

\begin{abstract}
In a sample taken from Apipucos Reservoir (Recife, PE, Brazil) for taxonomic study, a high percentage (40\%) was found of cladoceran Ilyocryptus spinifer individuals with morphological abnormalities on their postabdomen. There was not a fixed pattern of the malformations, which varied in gravity, and could affect the postanal spines or terminal claws. The postabdominal abnormalities are described and compared to the ones described in the literature. The hypothesis of the morphological abnormalities being induced by an occasional environmental toxicant is discussed.
\end{abstract}

Key words: Ilyocryptus spinifer, Cladocera, morphological abnormalities, Apipucos Reservoir.

\section{RESUMO}

\section{Anomalias morfológicas observadas no cladócero Ilyocryptus spinifer (Açude de Apipucos, Pernambuco, Brasil)}

Em uma amostra colhida no Açude de Apipucos (Recife, PE, Brasil), para estudos taxonômicos, foi encontrada alta porcentagem (40\%) de indivíduos do cladócero Ilyocryptus spinifer portadores de anomalias morfológicas no pós-abdome. Não se observou um padrão fixo de malformações, sendo de intensidade variável e podendo afetar os espinhos pós-anais ou as garras terminais. As anomalias são descritas e comparadas a outros casos registrados na literatura. Discute-se a hipótese de estarem relacionadas à contaminação por agentes tóxicos da água do Açude de Apipucos.

Palavras-chave: Ilyocryptus spinifer, Cladocera, anomalias morfológicas, Açude de Apipucos.

\section{INTRODUCTION}

Although not very frequently, morphological abnormalities in cladocerans have been reported (Frey, 1965; Røen, 1968; Smirnov, 1974; Shurin \& Dodson, 1997; Otha et al., 1998; Kotov \& Dumont, 2000; Sinev, 2000).

As pointed out by Røen (1968), the most common abnormalities observed in cladocerans are asymmetry in the appendages and sex integrades (individuals showing a mosaic of male and female features). But malformation of the postabdominal claws has also been reported (Røen, 1968; Smirnov, 1974; Shurin \& Dodson, 1997).

The causes of morphological abnormalities in microcrustaceans have not been properly investigated. Environments contaminated by industrial and urban waste have been associated with the occurrence of morphological anomalies in copepods and ostracods (Samir, 2000; Montu \& Gloeden, 1982; Dias, 1999), and bioassays have showed that some environmental toxicants can produce morphological abnormalities in cladocerans (Shurin \& Dodson, 1997; Otha et al., 1998). 
During a taxonomic study on Ilyocryptus spinifer Herrick, 1882 (Crustacea, Anomopoda, Ilyocryptidae), many abnormal individuals were found in a sample taken from Apipucos Reservoir, an urban reservoir in Northeast Brazil. The relevance of this observation lies in the high percentage of abnormal individuals (40\%) and the kinds of malformations observed, which have never before been reported for Ilyocryptus. Hence, the purpose of the present paper is to describe the morphological abnormalities observed in Ilyocryptus spinifer sampled from Apipucos Reservoir.

\section{MATERIAL AND METHODS}

The sample containing the abnormal individuals was taken in January 17, 2000, from the littoral zone of Apipucos Reservoir, which is located in the urban area of Recife, State of Pernambuco, Brazil (0801'16.6”'S; 3455'59"W).

To take the sample, some individuals of Eichhornia Kunth, 1843 (Pontederiaceae) were shaken into a recipient filled with reservoir water, which was then parsed through a plankton net. The filtered was preserved in formalin $4 \%$.

To estimate the frequency of abnormal individuals in the population, 75 individuals were randomly taken from the sample and observed under a microscope to verify their morphological features. Three categories of individuals were considered: normal, with minor abnormalities (when the postabdomen and its claws were not significantly modified and the postabdominal spines were reduced, but not absent), and with severe abnormality (when the postabdomen was modified and had lost most of its spines, and the terminal claws were also severely deformed or lost). In addition, individual length was taken, in order to verify if the abnormalities were correlated with the individual's age.

In September 7, 2001, a new sample was taken from the same place using the same method. As in the previous sample, 75 individuals were randomly taken, observed, and measured.

\section{RESULTS}

The abnormal individuals observed resembled the normal ones except for their postabdomens (Figs. 1-10). No morphological modifications were noticed with respect to their general shape, carapace, antenna, and antennules.

There was not a fixed pattern of postabdominal modification. Indeed, many different degrees of malformations were observed. The less severe one was the reduction or loss of some lateral and marginal postanal spines, with no modifications in the general postabdominal shape (Fig. 6). The most severe malformation observed was the complete loss of the terminal claws and the postanal spines (Fig. 10). Reduced and modified terminal claws were also observed (Figs. 4, 7-9).

All abnormal individuals were observed in the sample collected in January 17, 2000, and the frequency of malformations increased with the individual's size (Fig. 11). None of the smallest (or youngest) individuals presented postabdominal malformations, while the biggest (or oldest) individuals showed the most severe malformations. Furthermore, many of the abnormal individuals produced eggs (Fig. 2).

The population size distributions indicated by the two samples were different (Fig. 11). In January 17,2000 , the smaller the animals, the more frequent they were. The prevalence of small animals was also indicated by the average size $(0.43 \mathrm{~mm})$ of sample. However, in September 7, 2001, the most frequent class of size was $0.55-0.65 \mathrm{~mm}$, which included the sample average size $(0.57 \mathrm{~mm})$.

\section{DISCUSSION}

The frequency distribution of the abnormalities according to size (Fig. 11) suggests that they were induced by an environmental factor. The eggs produced by abnormal adults resulted, without exception, in normal postabdomens in the youngest individuals (Figs. $2 ; 11 \mathrm{~s})$. If the abnormal postabdomen was an inherited character, some young individuals should have showed it. Moreover, the non-fixed pattern of postabdominal abnormality and the absence of abnormal individuals in the second sample (Fig. 11) support the hypothesis of an acquired feature.

The occurrence of this abnormality-inducing environmental factor should be occasional or its concentration in water should be variable, as suggested by the absence of abnormalities in the youngest ones from the first sample and in the totality of the individuals from the second sample (Fig. 11). 

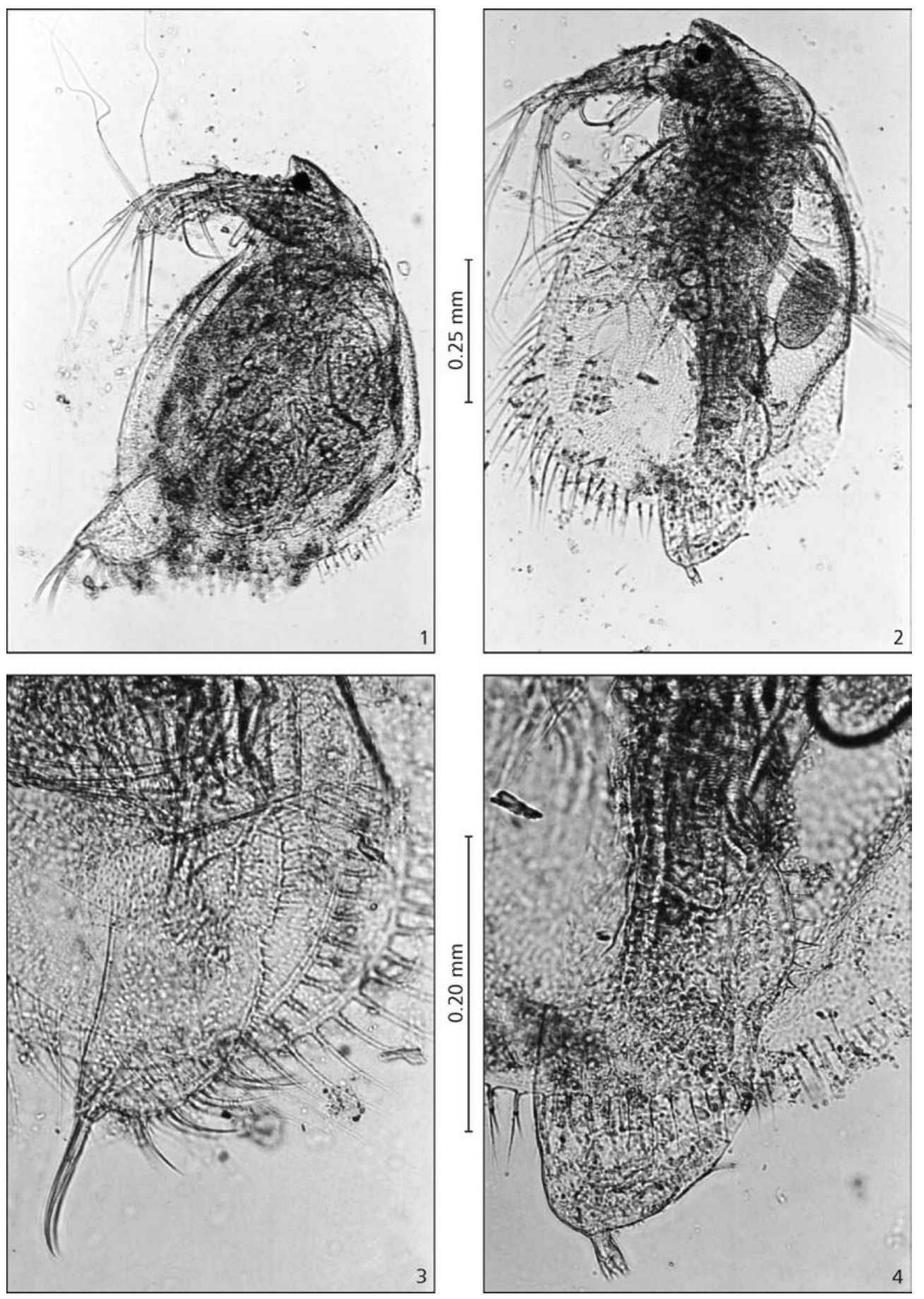

Figs. 1-4 - Ilyocryptus spinifer, female. 1 - Normal individual, lateral view. 2 - Abnormal individual, lateral view. 3 - Normal postabdomen. 4 - Abnormal postabdomen. 

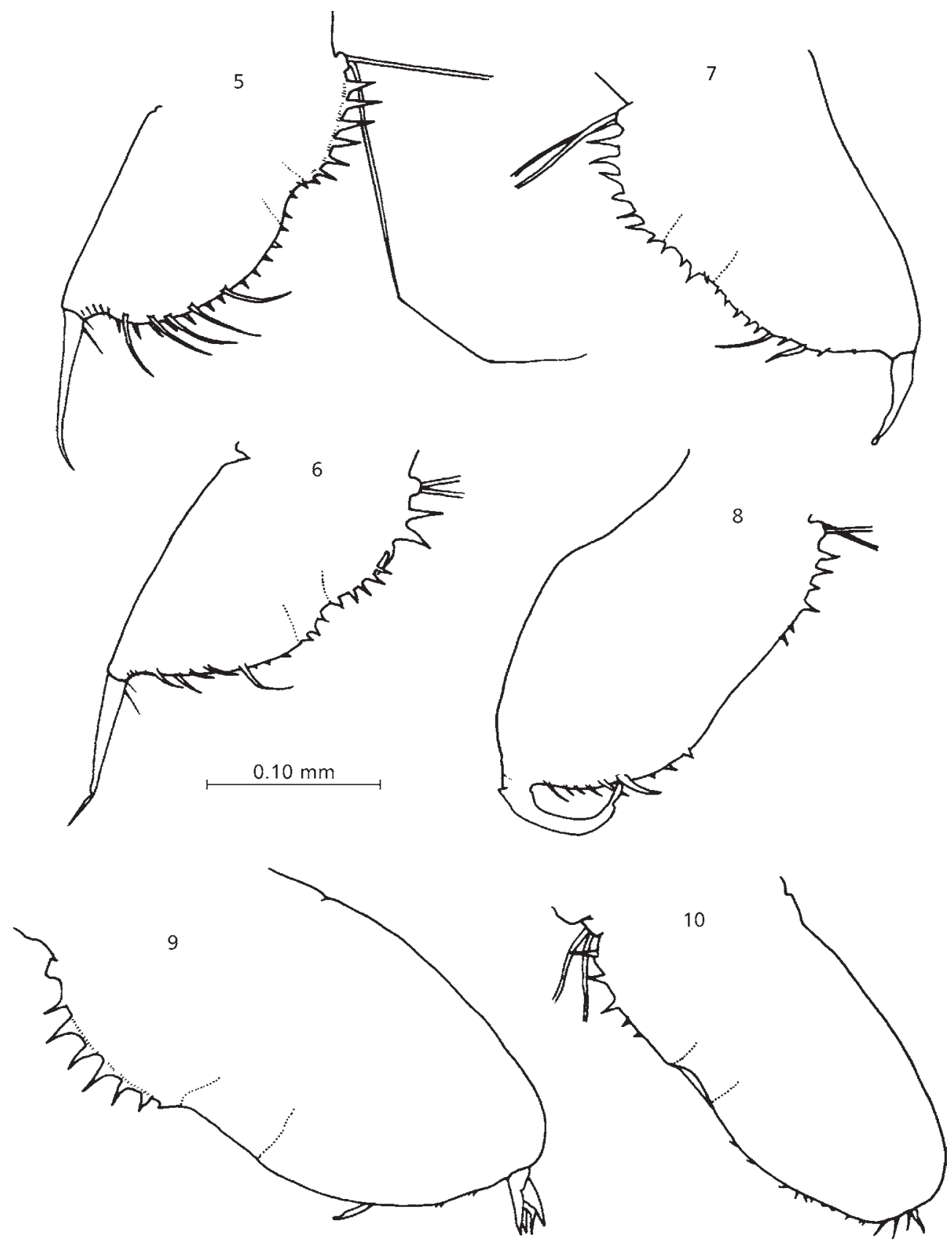

Figs. 5-10 - Ilyocryptus spinifer, female postabdomen. 5 - Normal. 6-7 - With minor abnormality. 8-10 - With severe abnormality. 


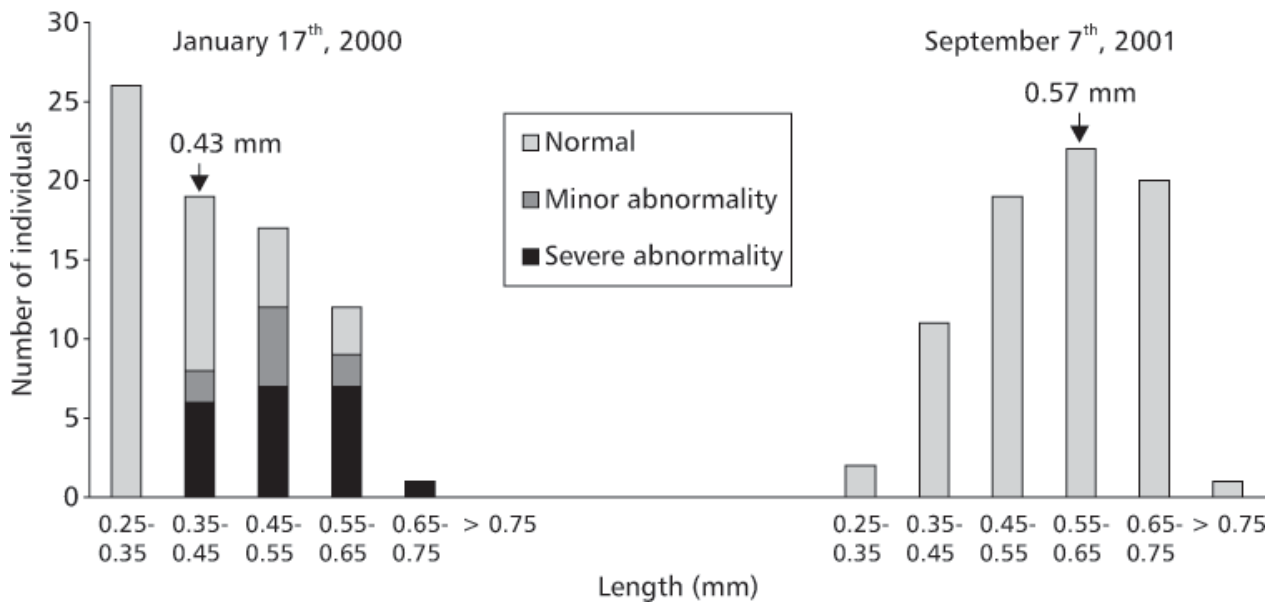

Fig. 11 - Frequency of malformations according to individual size in two samples taken from Apipucos Reservoir. Arrows indicate average length.

In their analysis of the Ilyocryptus spinifer species-group, Kotov \& Dumont (2000) described some abnormal individuals found in Sars' collection, which were regarded as probably due to the conditions of the culture in which they had grown. In some abnormal specimens, the postabdomen showed clusters of lateral spines instead of single elements, which is the normal pattern.

Hudec (2000) observed some malformations in the terminal claws of the Kurzia polyspina (Chydoridae), which he suggested could be "postreproductive characters by continual growth". Not excluding the possibility of continual growth in some individuals observed in I. spinifer from Apipucos Reservoir, this explanation could not be applied in all cases (e.g., the absence of terminal claws shown in Fig. 10). Moreover, Hudec's suggestion did not cite possible factors promoting continual growth.

On the other hand, bioassays have been conducted to test the effect of environmental toxicants on morphological abnormalities in cladocerans. Otha et al. (1998) showed that ethylenethiourea, a carcinogenic metabolite of ethylene-bisdithiocarbamate fungicides, could induce abnormalities in the Daphnia carapace.

Shurin \& Dodson (1997) tested the effects of nonylphenol, a non-ionic surfactant common in sewage effluents, on Daphnia (Daphniidae). They showed that, under experimental conditions, nonylphe- nol at environmentally relevant concentrations could produce malformations in Daphnia postabdomen and antenna. The postabdominal malformations described by these authors are similar to the ones observed in Ilyocryptus specimens from Apipucos Reservoir, suggesting that they had been induced by nonylphenol.

The Apipucos Reservoir is considered a eutrophic environment with heavy organic pollution. Besides the frequent spilling of domestic discharge, the reservoir is also impacted by oil-derivatives leaking from a gas station and by organic waste from pigsties, corrals, and poultry slaughterhouses (Neumann-Leitão et al., 1989). These circumstances are consistent with the suggestion that the observed morphological abnormalities in Ilyocryptus were induced by a toxicant.

Certainly, bioassays should be conducted to test the hypothesis of environmentally induced abnormality, and to verify the substance or substances responsible.

Although the results presented here are not conclusive, they show that morphological characters could be used as a biological parameter in future ecotoxicological research with cladocerans.

Moreover, the present results support the idea of using non-planktonic cladocerans as bioindicators of water quality, as previously proposed by Greve et al. (2000), who used benthic Chydorus sphaericus in toxicity tests. 
Aknowledgments - I am grateful to many colleagues for information and suggestions, in particular Sigrid NeumannLeitão (UFPE), William Severi (UFRPE), Eduardo M. da Silva (UFBA), Marco Antonio Souza, and Ricardo Silveira Bernardes (UnB). Special thanks are due to Ana Paula Barbosa de Brito for measuring Ilyocrytus individuals and Núcleo de Estudos Limnológicos (Departamento de Ecologia, UnB) for facilitating the use of photographic equipment. I also thank Ms. Vania Danigno for revising the English version of this manuscript. This study was financially supported by the Programa de Qualificação Docente of the Universidade Católica de Brasília.

\section{REFERENCES}

DIAS, C. O., 1999, Morphological abnormalities of Acartia lilljeborgi (Copepoda, Crustacea) in Espírito Santo Bay (ES, Brazil). Hydrobiologia, 394: 249-251.

FREY, D. G., 1965, Gynandromorphism in the Chydoridae Cladocera. Limnology and Oceanography, 10(suppl.): 103114.

GREVE, G. D., TER LAAK, T. L., BOIVIN, M. \& REEDE, T., 2000, The use of the benthic cladoceran Chydorus sphaericus for toxicity testing. Abstracts of the NABS Annual Meeting, Keystone, Colorado, 2000 [cited 30/08/2001]. Available from URL: http:// www.benthos.org/database/ allnabstracts/ctm/db/Keystone2000abstracts/id/206.

HUDEC, I., 2000, Subgeneric differentiation within Kurzia (Crustacea: Anomopoda: Chydoridae) and a new species from Central America. Hydrobiologia, 421: 165-178.

KOTOV, A. A. \& DUMONT, H. J., 2000, Analysis of the Ilyocryptus spinifer-species group (Anomopoda: Branchiopoda, with description of a new species. Hydrobiologia, 428: 85-113.
MONTU, M. \& GLOEDEN, I., 1982, Morphological alterations in Acartia tonsa (Saco da Mangueira, Lagoa dos Patos, Brasil). Arquivos de Biologia e Tecnologia, 25(3/4): 361369.

NEUMANN-LEITÃO, S., PARANHOS, J. D. N. \& DE SOUZA, F. B. V. A., 1989, Zooplâncton do Açude de Apipucos, Recife/Pe (Brasil). Arquivos de Biologia e Tecnologia, 32(4): 803-821.

OTHA, T., TOKISHITA, S., SHIGA, Y., HANAZATO, T. \& YAMAGATA, H., 1998, An assay system for detecting environmental toxicants with cultured cladoceran eggs in vitro: malformations induced by ethylenethiourea. Environmental Research, section A, 77: 43-48.

RØEN, V. I., 1968, Notes on abnormalites in freshwater Entomostraca with a description of a new subspecies, Alona affinis deudata. Vidensk. Maddr. Densk. Natuel. Foren, 131: 153-159.

SAMIR, A. M., 2000, The response of benthic foraminifera and ostracods to various pollution sources: a study from two lagoons in Egypt. Journal of Foraminiferal Research, 30(2): 83-98.

SHURIN, J. B. \& DODSON, S. I., 1997, Sublethal toxic effects of cyanobacteria and nonylphenol on environmental sex determination and development in Daphnia. Environmental Toxicology and Chemistry, 16(6): 1269-1276.

SINEV, A. Y., 2000, Postembryonal development of male and abnormal sexual individuals of Alona affinis (Leydig, 1860) (Anomopoda, Chydoridade). Hydrobiologia, 437: 197-202.

SMIRNOV, N. N., 1974, Chydoridae of the world's fauna. Fauna of the URSS-Crustacea, 1(2): 1-644. 